\title{
Science Communication in Multiple Languages Is Critical to Its Effectiveness
}

\author{
Melissa C. Márquez ${ }^{1}$ and Ana Maria Porras ${ }^{2 *}$ \\ ${ }^{1}$ School of Molecular and Life Sciences, Curtin University, Perth, WA, Australia, ${ }^{2}$ Meinig School of Biomedical Engineering, \\ Cornell University, Ithaca, NY, United States
}

Keywords: diversity, equity, global south, inclusion, media, multiculturalism, multilingualism, SciComm

\section{INTRODUCTION}

In 1967, English was recognized as the language of international science (Gordin, 2015) and it continues to dominate global scientific activities to this day. Around $80 \%$ of all journals indexed in SCOPUS are published in English (van Weijen, 2012). The linguistic domination of English is also observed in scientific journalism worldwide, which heavily depends on English-only sources (Nguyen and Tran, 2019). While the use of a single international language of science facilitates the dissemination of knowledge across national and cultural boundaries, the English language often acts as a gatekeeper to scientific discourse (Tardy, 2004).

The hegemony of English in science promotes and enforces the imposition of one particular cultural point-of-view over others (Alves and Pozzebon, 2013). By ignoring other languages, traditional mass media (e.g., newspapers, magazines), social media, and scientific journals ignore the cultures and perspectives of non-English speaking communities (Gibbs, 1995; Canagarajah, 1996, 2002; Kachru, 1997). A recent Google search (February, 2020) of the term "science" in 11 languages with the largest numbers of native speakers exemplifies the disproportionate dominance of English (Figure 1). It is clear that English is overrepresented in these search results, even after normalizing for the total number of native speakers per language (Figure 1). One explanation could be that the term "science" may not be as engaging and meaningful as other science-related terms in other languages. An alternative explanation could be that scientific communication in a language correlates with scientific activity in the corresponding countries. Such is the case in the field of bioinformatics, where the nations with the highest impact (h-index) are those that are the most active in academic publishing (Chasapi et al., 2020). Nonetheless, English search results are still $\sim 8$ times more popular even when compared to languages spoken in countries with a strong history of scientific production like Germany and Russia (Figure 1).

Facing the biggest existential threats to humanity requires understanding and support of science at a global scale, as exemplified by a multitude of climate-related natural disasters (Garcia Escobar and Rabanales, 2020; Stone, 2020) and the recent COVID-19 outbreak (Zarocostas, 2020). This opinion piece discusses some consequences of the (almost exclusive) use of English in the current global scientific landscape, and provides recommendations to expand both formal and informal science communication beyond the English language.

Received: 31 July 2019

Accepted: 22 April 2020

Published: 22 May 2020

\section{Consequences of the Use of English as the International Language of Science}

While having a "universal language of science" has allowed scientists to communicate ideas freely and gain access to global scientific literature, the primary use of a single language has created barriers for those who are non-native English speakers. For example, writing manuscripts and grants, preparing and presenting oral presentations, and general communication in English is much 
A

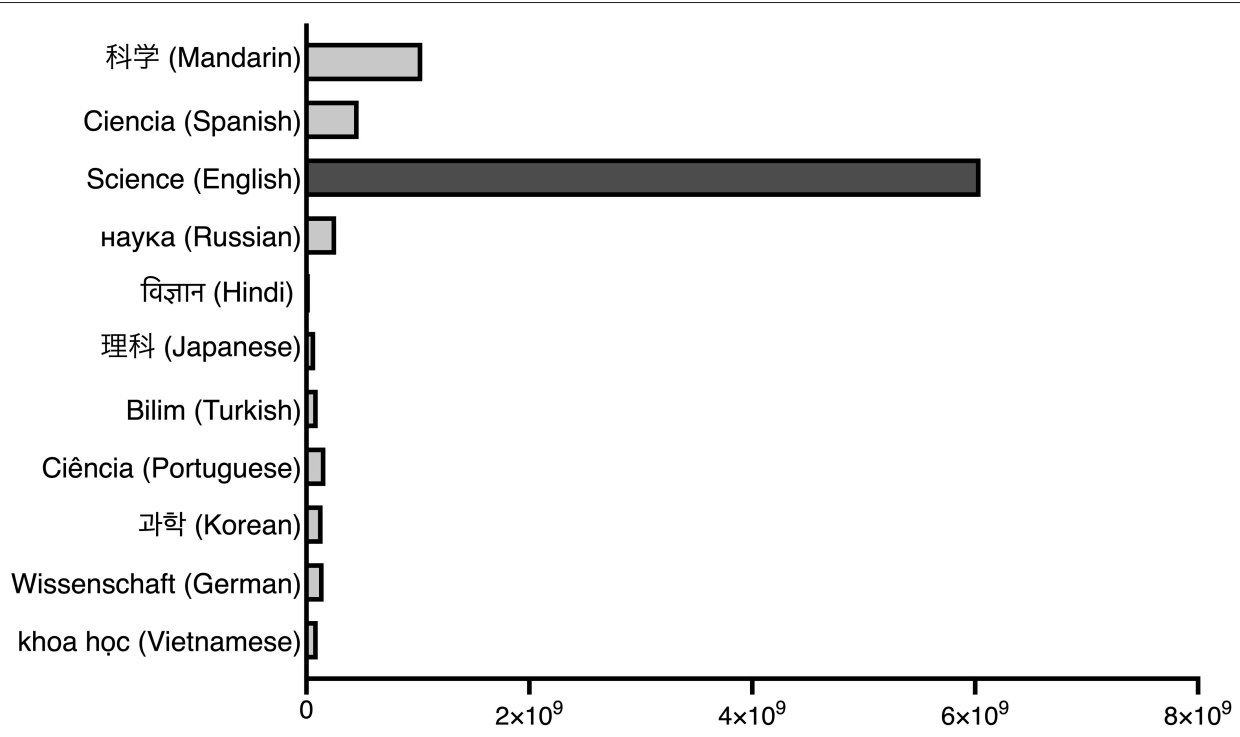

Google search results in February 2020

B

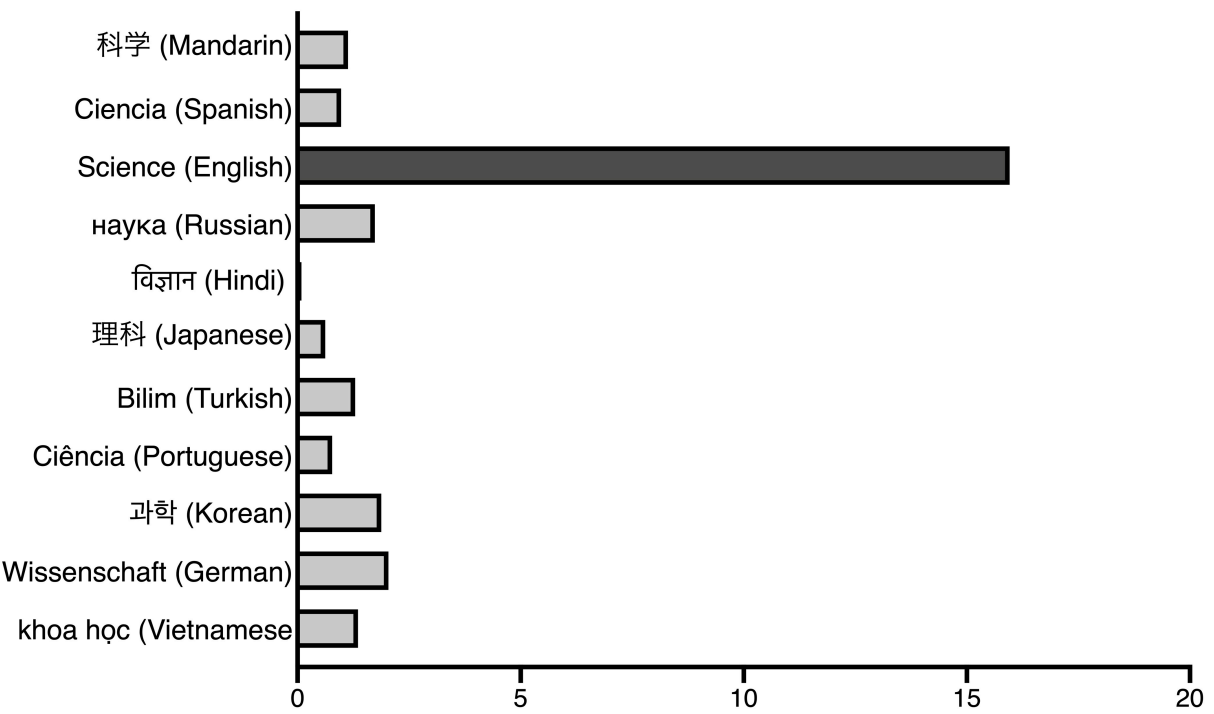

Google search results normalized to number of native speakers

FIGURE 1 | Google search results highlight the hegemony of English in science communication. (A) Google search results of the term "science" in multiple languages. Google searches were conducted on February 12, 2020 using 11 of the most widely spoken languages by number of native speakers (Eberhard et al., 2019).

Languages are organized from highest to lowest number of native speakers top to bottom. (B) Google search results of the term "science" in multiple languages normalized by the total number of native speakers per language.

more challenging for scientists with English as a Foreign Language (EFL) (Ramirez-Castaneda, 2020). EFL speakers report that the quality of English in their manuscripts under review, not the scientific content, is the primary target for criticism, limiting access to a fair chance at publication (Drubin and Kellogg, 2012). This English-only phenomenon creates challenges and gaps in the transfer of knowledge between communities (Amano et al., 2016).
Scientific discourse carried out in the native language of a target audience yields greater participation, motivation and optimism, and leads to stronger connections to concepts in the native culture (Manzini, 2000). Yet, most scientists today feel pressure to publish their papers in influential or globallyrecognized English journals that are regarded as yielding more citations (Di Bitetti and Ferreras, 2017) and having a higher impact than any in their mother tongue (Bortolus, 2012). 
On the SCImago Journal Rank, which ranks scientific journals on the citations their articles receive, the top 50 journals are published in English. Due to the hegemony of English-language science, the desire to publish in respected English journals has prompted journals that previously published in local languages (e.g., Animal Biodiversity and Conservation in Spain, Natureza \& Conservação in Brazil) to severely decrease or even cease publishing in their local language(s) to increase reach within the global scientific community.

There are ingrained systemic biases within larger institutional bodies (e.g., tenure requirements at universities or publication expectations at granting agencies) pushing scientists to publish work primarily in English (Bortolus, 2012). Similar biases and financial pressures in newsrooms worldwide contribute to the dominance of English in scientific journalism. However, as a consequence, scientific knowledge originating from non-English speaking countries (or pertaining to these regions) is not available in the local language(s). This means that for an individual, or entity, not knowing English limits their access to scientific information (Amano et al., 2016). Learning a new language is not always feasible; many communities do not have access to the educational tools and financial resources needed to learn a new language. In Colombia, high English-proficiency among scientists positively correlates with high-socioeconomic status (Ramirez-Castaneda, 2020). In addition, the time spent learning that language could be used instead for other purposes (e.g., conducting scientific research). Thus, the predominant use of English in science contributes to the widening of social and scientific inequities worldwide.

\section{Recommendations to Increase Multilingualism in Science Communication}

We, the authors of this Opinion, have spent the entirety of our professional careers in English-speaking settings away from our birthplaces and family. Frustrated by the lack of resources available in Spanish, our native tongue, each of us embarked on a path to create content in our native tongue and broaden access to scientific information. The recommendations in this piece were crafted based on our personal experiences, the cumulative experiences of like-minded colleagues, and evidence-based best practices backed by concrete examples of and studies in scientific communication. We propose some approaches to (1) expand access to scientific knowledge in languages other than English, (2) train STEM professionals and communicators to engage with local and global audiences through culturally-relevant strategies, and (3) encourage grassroots efforts to democratize science communication and create inclusive communities.

\section{Expand access to scientific knowledge in traditional publishing and mass media}

- For scientific journals: Translate research abstracts and articles to make them available in other languages.

The latest scientific findings are often unavailable to a large portion of the scientific community and the general public who are EFL speakers. This is particularly concerning in cases where this information is not accessible to the same communities and individuals that could benefit the most from the research. The onus should fall on scientific journals to begin to offer translations of at least the most widely read publications in their archive. Some journals like Emerging Themes in Epidemiology (Fung, 2008) are currently providing abstracts translated into other languages. To achieve this, publishers could enlist translating services from organizations like the American Translators Association or the International Association of Professional Translators and Interpreters. Other approaches have been described previously by Meneghini and Packer (2007). Additionally, the development of technology (e.g., by Google Translate) specifically designed for high-quality simultaneous translation of scientific writing would allow English-only speakers to share the burden of multilingual communication (Alves and Pozzebon, 2013). These practices, in conjunction with Open Access policies, will begin to even the scientific playing field.

- For media in English-speaking societies: Highlight scientists working in settings where English is not the native language.

The bias to publish in English is not only limited to academic journals but is also prevalent in global mass media (e.g., newspapers, television, radio, blogs). An unintended consequence is the lack of coverage of scientists working in areas where other languages are spoken, primarily in low and middle-income countries. News outlets should consider diversifying the types of scientists that are highlighted to ensure more backgrounds are represented and, wherever possible, providing translations of published stories in the relevant native language. The Forbes online science division, for example, has recently made an effort (primarily led by journalist Andrew Wight), to increase the coverage of science stories across countries in Asia, Africa, and Latin America (Wight, 2020).

- For media in societies where English is not the native language: Increase local science coverage.

Scientists who are not fluent in English struggle to gain recognition for their work, sometimes including in their own countries. Moreover, newspapers and traditional mass media in non-English speaking parts of the world often do not employ science journalists and instead rely on press releases from the Associated Press and other international news sources that do not cover local scientific discoveries (Nguyen and Tran, 2019). As a result, local findings go unreported and support for local science wanes. Greater support for and training in scientific journalism worldwide is needed to advance these local efforts. People trust leaders whose values and worldviews align with their own (Fiske and Dupree, 2014). Thus, enlisting local professionals who can better relate to the intended audiences is crucial. Networks like Agência Bori in Brazil that connect scientists to journalists could help facilitate these types of connections (Estarque, 2020).

- Create culturally relevant content.

Truly inclusive scientific communication requires audience engagement through approaches that recognize the voices and experiences of the target community (Canfield et al., 
2020). Simple translations of existing content are insufficient to capture attention and present complex information in an understandable manner. Instead, scientists and content creators in both traditional and social media should employ culturally-relevant expressions, metaphors (Taylor and Dewsbury, 2018), experiences (Djonko-Moore et al., 2018), and storytelling approaches (Dahlstrom, 2014; HunterDoniger et al., 2018). For example, a soccer (fútbol) analogy might be more appropriate in many parts of the world than an American football metaphor. News outlets and budding science communicators can look to journalist Sibusiso Biyela's work in South Africa as an example of the successful integration of creative storytelling in native contexts (Kwon, 2019).

\section{Training STEM professionals and communicators}

- Train scientists and communicators to engage with and relate to diverse audiences.

Independent of the language of choice, the success of any initiative seeking to communicate science depends on the ability of the scientist/communicator to engage with the audience. This can be achieved through a variety of methods including (but not limited to) storytelling (Green et al., 2018), art as a communication tool (Lesen et al., 2016), and citizen science (Phillips et al., 2019). All of these approaches can and should be adapted to incorporate the local languages, practices, and cultural norms relevant to the target audience; however, STEM students and professionals are rarely trained on these strategies. To fully integrate STEM into strategies for societal progress, it is imperative for academic institutions and national science agencies worldwide to implement multicultural science communication training programs at all career levels. Organizations and initiatives like the Massive Science Consortium, Reclaiming STEM, the Biota Project (Cheng et al., 2018), the "Communicating Ciencia" workshop (Landis et al., 2020), and the Inclusive SciComm symposium (Canfield et al., 2020) are already implementing inclusive training strategies that could be adapted to other languages and cultures.

- Encourage and support STEM students and professionals to seek opportunities to talk about their work in their native tongue.

Numerous STEM professionals leave home to work and train in a location where English is the primary language. Even when pursuing a career in their home countries, systemic pressures encourage these scientists to prioritize English-only opportunities (Tardy, 2004). Therefore, the ability to discuss, present, and write about science in their native tongue(s) can be severely compromised. This is especially true for scientists from indigenous communities, whose worldviews often get erased as a result from scientific discourse (Ammon, 2011). Attending conferences and events to disseminate one's work is highly valued by universities and institutions; however, these international events rarely (if ever) feature languages outside of English. Additionally, local events to present one's research to lay audiences in languages other than English is often not supported by both supervisors and institutions even though multilingual fluency is fundamental for science on a global scale. Trainees and faculty should be encouraged to pursue and participate in events and activities that allow them the opportunity to share their work in their native language(s).

Some organizations and universities have taken it upon themselves to share fundamental scientific knowledge with communities that have difficulty accessing formal education and scientific information in their own language(s). For example, Clubes de Ciencia is a non-profit organization that offers STEM workshops for high-school and college students throughout Spain and Latin America (Ferreira et al., 2019). Similarly, the Imagine Project at the Federal University of Santa Catarina in Brazil promotes scientific inclusion and cultural exchange by translating scientific videos into indigenous languages (with subtitles) that are shared with remote communities (Ramos and Empinotti, 2017). These types of efforts are crucial to encourage the decolonization of science, expand access to scientific knowledge, and even participate in the active protection of endangered languages.

\section{Encouraging grassroots efforts}

- Take advantage of the ubiquity and accessibility of social media platforms to reach a wider diversity of audiences.

Social media platforms have become ubiquitous and powerful tools for the dissemination of information. Over the past 10 years, social media use has grown from 7 to $65 \%$ of adults worldwide (Perrin-Cocon et al., 2013). As a consequence, the landscape in which science communication takes place is changing. Researchers are no longer discussing their findings exclusively via publications in scientific journals or high-profile magazine articles. They are also engaging with other scientists and various audiences through social media outlets like Twitter and Instagram. These platforms are available to scientists globally at low or no financial cost and, as a result, STEM professionals and communicators are increasingly interested in using social media for public engagement (Pew Research Center, 2015). If these networks were used in conjunction with strategies to support efforts in languages other than English, they could effectively lower the barriers of access to knowledge worldwide. Science YouTube channels like Ciencia Café Pa Sumercé (Colombia), Научпоk (Russia), Kainaat (Pakistan), and Manual do Mondo (Brazil) are currently producing engaging and culturally relevant content within their respective countries. Recent research has demonstrated the effectiveness of engaging with audiences on social media platforms, like Instagram, to counteract negative perceptions of scientists (Brown Jarreau et al., 2019).

- Create communities where scientific communicators in different languages can interact with one another.

The practice of science communication is no longer limited to celebrity scientists like Bill Nye the Science Guy or Neil deGrasse Tyson; it is now available to anyone with access to 
social media outlets. Science communicators are important in keeping science in the public eye. However, this is often seen as an unimportant efforts when compared to publishing articles and attending conferences, and therefore engaging in these efforts can be isolating. Increasingly, researchers are turning to social media to form supportive communities, where content creators/communicators can collaborate.

Social media and other digital platforms could help facilitate collaboration. For example, the "STEM Squad" community on Facebook, centered on the advancement and inclusion of women in STEM careers, has become an important resource by increasing the representation of marginalized scientists in the public lens, financially supporting innovative projects for outreach and inclusion, and creating a space for multilingual conversations. Similarly, the "Joe’s Big Idea" Slack community offers a private space for scientific communicators to share resources and opportunities, ask questions, and engage with others interested in communicating in other languages. Unified hashtags (like \#WissComm [\#SciComm] and \#ComunicaCiencia [\#CommunicateScience] used by German- and Spanish-speakers, respectively) can help pool engagement efforts in the chosen language. For in-person support, organized events to celebrate science like Science Festivals (Bultitude et al., 2011) can allow researchers to meet face-to-face and share their science with the greater public in their native language(s).

\section{CONCLUSIONS}

There is a language bias in the current global scientific landscape that leaves non-English speakers at a disadvantage and prevents them from actively participating in the scientific process both as scientists and citizens. Science's language bias extends beyond words printed in elite English-only journals. It manifests in how science is reported in mass and social media outlets, in the researchers represented in the media, and often in the lack of contact between communities and their local scientists. Exposure to diverse role models has profound effects on aspiring young scientists, as exemplified by the "Scully effect" reported by the Geena Davis Institute on Gender in Media. In this study, $63 \%$ of surveyed women in STEM specifically cited Dana Scully's character in The XFiles as increasing their belief in the importance of STEM (Geena Davis Institute of Gender in Media, 2018). Beyond

\section{REFERENCES}

Alves, M. A., and Pozzebon, M. (2013). How to resist linguistic domination and promote knowledge diversity? Rev. Adm. Empres. 53, 629-633. doi: 10.1590/S0034-759020130610

Amano, T., González-Varo, J. P., and Sutherland, W. J. (2016). Languages are still a major barrier to global science. PLoS Biol. 14:e2000933. doi: 10.1371/journal.pbio.2000933

Ammon, U. (2011). The Dominance of English as a Language of Science: Effects on Other Languages and Language Communities. Mouton de Gruyter. Available representation, access to scientific knowledge is also a matter of equity and fairness.

The National Science Education Standards defines science literacy as "the knowledge and understanding of scientific concepts and processes required for personal decision making, participation in civic and cultural affairs, and economic productivity" (National Academy of Sciences, 1996). Previous work has demonstrated that democratic societies that are scientifically literate make equitable choices regarding sciencerelated policy issues (European Commission, 1995; Rudolph and Horibe, 2016). Thus, effective communication of science and science literacy are socioeconomically imperative for all societies. Considering basic science is primarily funded by government funds in many countries (OECD, 2015), access to and understanding of science is also a right for tax-paying citizens around the world.

There are multiple steps-many outlined in this manuscriptjournal publishers, media outlets, academic institutions, and government agencies should take to improve how science is communicated around the world. The burden of these efforts should not fall exclusively on the shoulders of EFL speakers. As long as English remains the gatekeeper to scientific discourse, people of other cultural backgrounds will continue to find it increasingly difficult to participate in the scientific process and benefit from its outcomes. We hope this piece sparks new discussions within the ongoing conversation around developing effective strategies for multilingual and inclusive outreach efforts to communicate scientific content formally and informally. The future of the scientific enterprise worldwide depends on it.

\section{AUTHOR CONTRIBUTIONS}

MM and AP contributed equally to this manuscript in its conception, writing, and editing.

\section{FUNDING}

AP was funded by a Cornell Presidential Postdoctoral Fellowship.

\section{ACKNOWLEDGMENTS}

The authors would like to thank Valeria Ramírez-Castañeda for her suggestions to improve the recommendations in this manuscript.

online at: https://books.google.com/books?hl=en\&lr=\&id=- qkUlGnAs0kC\& oi $=$ fnd \&pg $=$ PR $5 \& \mathrm{dq}=$ science $\$+\$$ communication+indigenous+languages $\&$ ots=I9pNVMmq_M\&sig=cWGoGlmml-zfKiZbQNYNY_85T_w\#v= onepage\&q=indigenous\&f=false (accessed February 21, 2020).

Bortolus, A. (2012). Running like alice and losing good ideas: on the quasicompulsive use of english by non-native english speaking scientists. Ambio 41, 769-772. doi: 10.1007/s13280-012-0339-5

Brown Jarreau, P., Cancellare, I. A., Carmichael, B. J., Porter, L., Toker, D., and Yammine, S. Z. (2019). Using selfies to challenge public stereotypes of scientists. PLoS ONE 14:e0216625. doi: 10.1371/journal.pone.0216625 
Bultitude, K., McDonald, D., and Custead, S. (2011). The rise and rise of science festivals: an international review of organised events to celebrate science. Int. J. Sci. Educ. B Commun. Public Engagem. 1, 165-188. doi: 10.1080/21548455.2011.588851

Canagarajah, A. S. (1996). "Nondiscursive" requirements in academic publishing, material resources of periphery scholars, and the politics of knowledge production. Writ. Commun. 13, 435-472. doi: 10.1177/0741088396013 004001

Canagarajah, A. S. (2002). A Geopolitics of Academic Writing. University of Pittsburgh. Available online at: https://digital.library.pitt.edu/islandora/object/ pitt:31735062136514 (accessed February 21, 2020).

Canfield, K. N., Menezes, S., Matsuda, S. B., Moore, A., Mosley Austin, A. N., Dewsbury, B. M., et al. (2020). Science communication demands a critical approach that centers inclusion, equity, and intersectionality. Front. Commun. 5:2. doi: $10.3389 /$ fcomm.2020.00002

Chasapi, A., Promponas, V. J., and Ouzounis, C. A. (2020). The bioinformatics wealth of nations. Bioinformatics. btaa132. doi: 10.1093/bioinformatics/ btaa 132

Cheng, H., Dove, N. C., Mena, J. M., As Perez, T., and Ul-Hasan, S. (2018). The biota project: a case study of a multimedia, grassroots approach to scientific communication for engaging diverse audiences. Integr. Comp. Biol. 58, 1294-1303. doi: 10.1093/icb/icy091

Dahlstrom, M. F. (2014). Using narratives and storytelling to communicate science with nonexpert audiences. Proc. Natl. Acad. Sci. U.S.A. 111, 13614-13620. doi: 10.1073/pnas.13206 45111

Di Bitetti, M. S., and Ferreras, J. A. (2017). Publish (in English) or perish: the effect on citation rate of using languages other than English in scientific publications. Ambio 46, 121-127. doi: 10.1007/s13280-0160820-7

Djonko-Moore, C. M., Leonard, J., Holifield, Q., Bailey, E. B., and Almughyirah, S. M. (2018). Using culturally relevant experiential education to enhance urban children's knowledge and engagement in science. J. Exp. Educ. 41, 137-153. doi: 10.1177/1053825917742164

Drubin, D. G., and Kellogg, D. R. (2012). English as the universal language of science: opportunities and challenges. Mol. Biol. Cell 23:1399. doi: 10.1091/mbc.E12-02-0108

Eberhard, D. M., Simons, G. F., and Fennig, C. D. (2019). Ethnologue: Languages of the World. Twenty-Sec. Dallas, TX: SIL International.

Estarque, M. (2020). Periodistas brasileñas crean plataforma para conectar científicos y prensa knight center for journalism in the americas. Knight Center for Journalism in the Americas. Available online at: https://knightcenter. utexas.edu/es/blog/00-21603-periodistas-brasilenas-crean-plataforma- paraconectar-cientificos-y-prensa (accessed February 20, 2020).

European Commission (1995). White Paper on Education and Training. Brussels. Available online at: https://publications.europa.eu/en/publication-detail/-/ publication/d0a8aa7a-5311-4eee-904c-98fa541108d8/language-en (accessed July 30, 2019).

Ferreira, L. M. R., Carosso, G. A., Montellano Duran, N., Bohorquez-Massud, S. V., Vaca-Diez, G., Rivera-Betancourt, L. I., et al. (2019). Effective participatory science education in a diverse latin American population. Palgrave Commun. 5:63. doi: 10.1057/s41599-019-0275-0

Fiske, S. T., and Dupree, C. (2014). Gaining trust as well as respect in communicating to motivated audiences about science topics. Proc. Natl. Acad. Sci. U.S.A. 111, 13593-13597. doi: 10.1073/pnas.1317505111

Fung, I. C. (2008). Open access for the non-English-speaking world: overcoming the language barrier. Emerg. Themes Epidemiol. 5:1. doi: 10.1186/1742$7622-5-1$

Garcia Escobar, J., and Rabanales, M. (2020). Drought and hunger: why thousands of guatemalans are fleeing north. Guard. Available online at: https:// www.theguardian.com/global-development/2020/feb/07/guatemala-hungerfamine-flee-north (accessed February 22, 2020).

Geena Davis Institute of Gender in Media (2018). "The scully effect: I want to believe in STEM," in 21st Century Fox, Geena Davis Institute on Gender in Media, and J. Walter Thompson Intelligence. Available online at: https://seejane.org/research-informs-empowers/the-scully-effect-iwant-to-believe-in-stem/ (accessed February 20, 2020).
Gibbs, W. W. (1995). Lost science in the third world - scientific American. Sci. Am. 273, 92-99. doi: 10.1038/scientificamerican 0895-92

Gordin, M. D. (2015). Scientific Babel: How Science Was Done Before and After Global English. Chicago, IL: University of Chicago Press.

Green, S. J., Grorud-Colvert, K., and Mannix, H. (2018). Uniting science and stories: perspectives on the value of storytelling for communicating science. FACETS 3, 164-173. doi: 10.1139/facets-20160079

Hunter-Doniger, T., Howard, C., Harris, R., and Hall, C. (2018). STEAM through culturally relevant teaching and storytelling. Art Educ. 71, 46-51. doi: 10.1080/00043125.2018.1389593

Kachru, B. B. (1997). World englishes and english-using communities. Annu. Rev. Appl. Linguist. 17, 66-87. doi: 10.1017/s0267190500 003287

Kwon, D. (2019). Decolonizing science through sci comm. Symmetry Magazine. Available online at: https://www.symmetrymagazine.org/article/decolonizingscience-through-sci-comm (accessed February 19, 2020).

Landis, B. Y., Bajak, A., de la Hoz, J. F., González, J. G., Gose, R., Tibbs, C. P., et al. (2020). CómoSciWri: resources to help science writers engage bicultural and bilingual audiences in the United States. Front. Commun. 5:10. doi: 10.3389/FCOMM.2020.00010

Lesen, A. E., Rogan, A., and Blum, M. J. (2016). Science communication through art: objectives, challenges, and outcomes. Trends Ecol. Evol. 31, 657-660. doi: 10.1016/J.TREE.2016.06.004

Manzini, S. T. (2000). The influences of a culturally relevant physical science curriculum on the learning experiences of African children (Master's thesis), University of Durban-Westville, Durban, South Africa.

Meneghini, R., and Packer, A. L. (2007). Is there science beyond English? EMBO Rep. 8, 112-116. doi: 10.1038/sj.embor.7400906

National Academy of Sciences (1996). National Science Education Standards. Washington, DC: National Academies Press. doi: 10.17226/ 4962

Nguyen, A., and Tran, M. (2019). Science journalism for development in the global south: a systematic literature review of issues and challenges. Public Underst. Sci. 28, 973-990. doi: 10.1177/0963662519875447

OECD (2015). OECD Science, Technology and Industry Scoreboard 2015: Innovation for Growth and Society, Paris: OECD Publishing.

Perrin-Cocon, L., Diaz, O., André, P., and Lotteau, V. (2013). Modified lipoproteins provide lipids that modulate dendritic cell immune function. Biochimie 95, 103-108. doi: 10.1016/j.biochi.2012. 08.006

Pew Research Center (2015). How Scientists Engage the Public. Pew Research Center. Available at: https://www.pewresearch.org/science/2015/02/15/howscientists-engage-public/ (accessed February 19, 2020).

Phillips, T. B., Ballard, H. L., Lewenstein, B. V., and Bonney, R. (2019). Engagement in science through citizen science: moving beyond data collection. Sci. Educ. 103, 665-690. doi: 10.1002/sce.21501

Ramirez-Castaneda, V. (2020). Disadvantages of writing, reading, publishing and presenting scientific papers caused by the dominance of the English language in science: the case of Colombian Ph.D. in biological sciences. bioRxiv [Preprint]. Available online at: https://www.biorxiv.org/content/10.1101/2020. 02.15.949982v2 (accessed May 4, 2020).

Ramos, A., and Empinotti, M. (2017). Indigenous languages must feature more in science communication. Conversat. Available online at: http://theconversation. com/indigenous-languages-must-feature-more-in-science-communication88596 (accessed February 20, 2020).

Rudolph, J. L., and Horibe, S. (2016). What do we mean by science education for civic engagement? Wiley Period. Inc. J Res Sci Teach 53, 805-820. doi: 10.1002/tea.21303

Stone, M. (2020). East Africa's plague of locusts and the bizarre climate science behind it. Natl. Geographic Magazine. Available online at: https://www. nationalgeographic.com/science/2020/02/locust-plague-climate-science- eastafrica/ (accessed February 22, 2020).

Tardy, C. (2004). "The role of English in scientific communication: Lingua Franca or Tyrannosaurus rex?", in J. English Acad. Purp. 3, 247-269. doi: 10.1016/j.jeap.2003.10.001 
Taylor, C., and Dewsbury, B. M. (2018). On the problem and promise of metaphor use in science and science communication. J. Microbiol. Biol. Educ. 19:19.1.46. doi: 10.1128/jmbe.v19i1.1538

van Weijen, D. (2012). The Language of (Future) Scientific Communication. Research Trends, 31 .

Wight, A. (2020). This scientist from zimbabwe is helping make African STEM more visible. Forbes. Available online at: https://www.forbes.com/sites/ andrewwight/2020/02/02/this-scientist-from-zimbabwe-is-helping-makeafrican-stem-more-visible/\#69ddb5fc57f7 (accessed February 22, 2020).

Zarocostas, J. (2020). What next for the coronavirus response? Lancet 395:401. doi: 10.1016/S0140-6736(20)30292-0
Conflict of Interest: The authors declare that the research was conducted in the absence of any commercial or financial relationships that could be construed as a potential conflict of interest.

Copyright (๑) 2020 Márquez and Porras. This is an open-access article distributed under the terms of the Creative Commons Attribution License (CC BY). The use, distribution or reproduction in other forums is permitted, provided the original author(s) and the copyright owner(s) are credited and that the original publication in this journal is cited, in accordance with accepted academic practice. No use, distribution or reproduction is permitted which does not comply with these terms. 